\title{
The status of the snow leopard in Pakistan and its conflict with local farmers
}

\author{
Shafqat Hussain
}

\begin{abstract}
Between 1998 and 2001 I carried out surveys in four areas in the Baltistan district of the Northern Areas of Pakistan to estimate the population of the snow leopard and to examine the threats to its future conservation. I estimate that a total of 36-50 snow leopards are present in the areas surveyed. Based on the availability of suitable snow leopard habitat and of its prey species, I estimate that 90-120 snow leopards are potentially present in Baltistan and 300-420 throughout its range within Pakistan's borders. Although this estimate is higher than extrapolations based on earlier surveys, the long-term future of the snow leopard is under threat.
\end{abstract}

This is mainly due to retaliatory killings by farmers, and poaching for pelts and other body parts. Speciesfocused conservation policies, particularly those targeting ungulates for the promotion of trophy hunting, may constitute an additional threat to snow leopard conservation in the region. However, all forms of threats to the snow leopard in Baltistan appear to emanate from the relatively poor economic conditions of the local people.

Keywords Central Karakorum, farmer-wildlife conflict, livestock predation, snow leopard, Uncia uncia, Western Himalayas.

\section{Introduction}

The snow leopard Uncia uncia is widely but thinly distributed throughout its range in the mountains of Central Asia. The core habitat of this species is the Himalayan mountain system, which includes the Altay, Tien Shan, Kun Lun, Pamir, Hindu Kush, Karakoram, and Himalaya mountain ranges, in the countries of Afghanistan, China, India, Kyrgyztan, Kazakistan, Mongolia, Pakistan, Tajikistan and Uzbekistan. It is also found in the Siberian region of Russia, and in Bhutan and Nepal. The snow leopard is categorized as Endangered in the 2002 IUCN Red List (IUCN, 2002), Endangered under the US Endangered Species Act (1973), and it is listed on Appendix I of the Convention on International Trade in Endangered Species (CITES), which means that trade in the animal and its body parts is illegal.

The snow leopard is found throughout the mountain ranges of the north of Pakistan (Fig. 1a), in all five districts of the federally administered Northern Areas, in the Chitral, Dir, Swat and Kohistan districts of the North West Frontier Province, and Muzaffar Abad district of Pakistani Kashmir (Malik, 1997). The total snow leopard habitat available in Pakistan is $c .80,000 \mathrm{~km}^{2}$ of

Shafqat Hussain C/O AKRSP, Forestry Section, P.O. Box 610, Sadpara Road, Skardu, Baltistan, Northern Areas, Pakistan.

Present address: School of Forestry and Environmental Studies, Yale University, New Haven, CT 06511, USA. E-mail: shafqat.hussain@yale.edu

Received 23 March 2001. Revision requested 7 June 2001 Accepted 26 September 2002 which c. $40,000 \mathrm{~km}^{2}$ is considered to be prime habitat (Fox, 1989). Schaller (1976) estimated that the number of snow leopard in Pakistan could be 100-250. Malik (1997) reported that the number could be c. $400 \pm 50$. Estimates of localized populations exist for Chitral, Chitral Gol National Park (Malik, 1997) and Khunjerab National Park (Wegge, 1989). Since 1977, although there have been small, localized surveys (IUCN, 1997a, b), there has been no attempts, based on recent surveys, to estimate the size of the population of snow leopard in the mountains of Pakistan.

The purpose of this study was twofold. Firstly, to investigate the status and distribution of the snow leopard population in the Baltistan district of Pakistan (Fig. 1) and, based on the availability of suitable habitat and prey, to estimate the snow leopard population in Pakistan. Secondly, to examine the threats faced by this snow leopard population.

\section{Study area}

The general study area lies in the north-east of Pakistan in the Baltistan district of the federally administered Northern Areas (Fig 1), which comprises the Central Karakoram and Western Himalayan mountain ranges. Within this area, four potentially important areas of snow leopard habitat were surveyed.

Area A lies in the Saltoro range and Hushey valley, and includes the villages of Hushey, Kandey, Dumsam and Kondas. The area is characterized by rugged and broken terrain. The mountain slopes are extremely steep $\left(>50^{\circ}\right)$, and valleys are narrow with good travel routes 

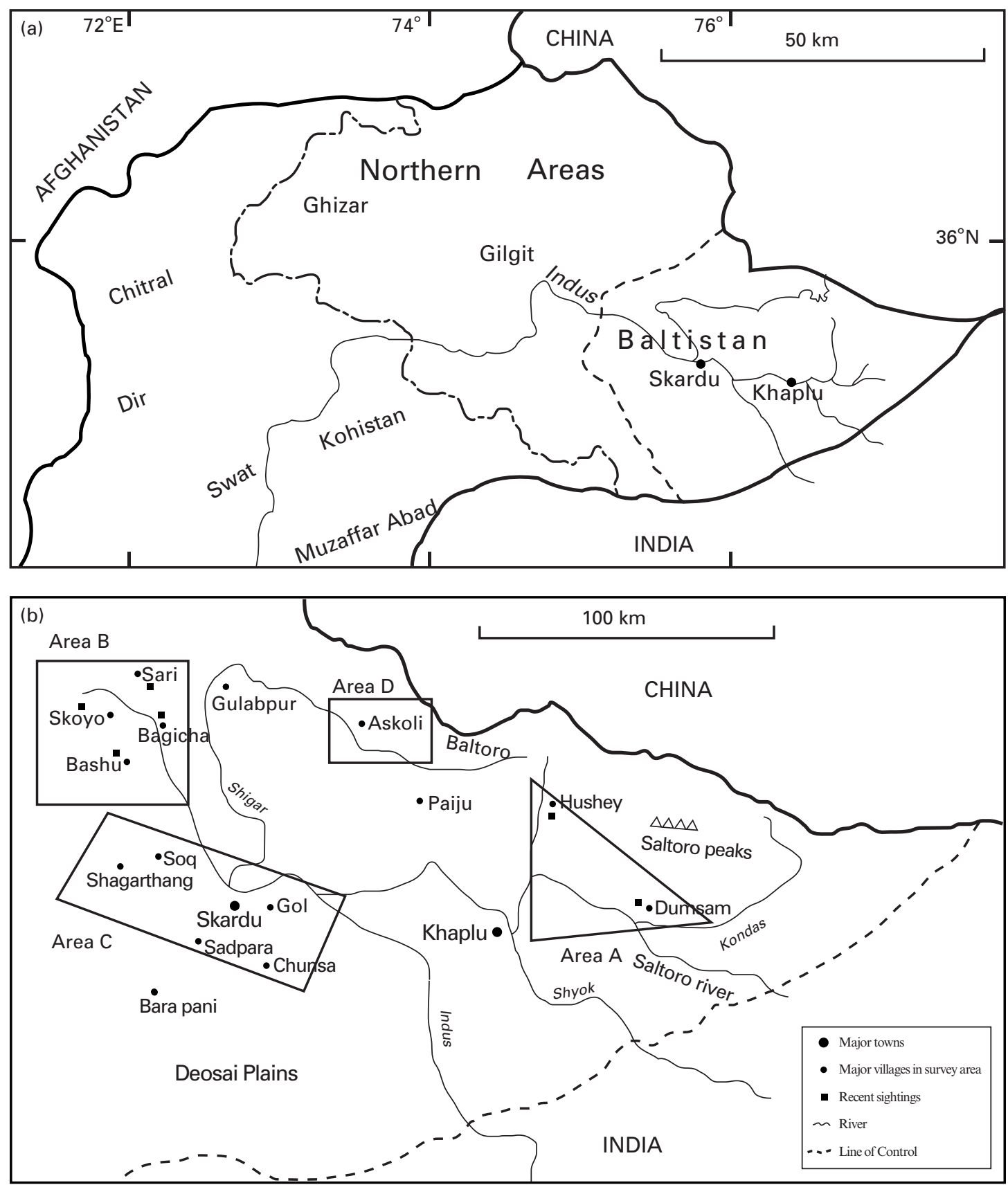

Fig. 1 (a) The general range of the snow leopard in north-east Pakistan: the districts of Chitral, Dir, Swat and Kohistan in the North West Frontier Province, Muzaffar Abad district of Pakistani Kashmir, and the Northern Areas, including the district of Baltistan. (b) The four areas, A-D, surveyed in Baltistan, with locations of recent snow leopard sightings.

for the snow leopard. IUCN (1997a) reported that snow leopard presence signs were common in the area in 1996 and 1997, and estimated that at least 8-10 snow leopards were active in an $800 \mathrm{~km}^{2}$ area around Hushey village.

Area B lies c. $70 \mathrm{~km}$ west of the town of Skardu, and includes the villages of Skoyo and Basho located on the south bank of the river Indus, and the villages of Sari and Baghicha on the northern bank. Skoyo and Basho are bounded to the south by the Deosai Plains and Astor district, and Sari and Bagicha are bounded to the north by Shigar valley. The area is a prime snow leopard habitat, with broken terrain and craggy mountain peaks. A small population of Astor markhor Capra falconer falconeri occurs in this area.

Area $C$ is the mountain ranges to the south and east of Skardu valley, including the villages of Shagarthang, 
Soq, Sadpara, Khepchun and Gol. The area stretches south from Kachura settlement on the Indus, through Soq Valley to the village of Shagarthang. Overall the area is better habitat for wolves than snow leopards, but there are areas of good snow leopard habitat on the eastern mountain slopes of Soq valley, Chunsa valley on the eastern bank of Sadpara Lake, and the adjacent Thurgo massif and the Khepchun La.

Area D includes parts of Baltoro and Biafo glaciers in the vicinity of Askoli village in Shigar valley. The area stretches west along the Biafo glacier and is connected with the Nagar and Shimshal valleys in Gilgit district. This area, stretching from Askoli through the BiafoHispar glaciers, covering Shimshal valley and up to Khunjerab National Park at the border with China near Taxkorgan, is the core area for snow leopards in the central Karakoram range.

\section{Methods}

I carried out surveys for snow leopard in Baltistan during 1998-2001, investigating a total of $3,150 \mathrm{~km}^{2}$ of prime snow leopard habitat in areas A, B and C. I surveyed a total of $130 \mathrm{~km}$ of transects on foot in randomly selected areas for signs of snow leopard presence (pug marks, scat and scrapes). Signs of the snow leopard are clearly distinguishable from those of the wolf Canis lupus. The scat of the two species is shaped differently, and pug marks can be distinguished by the absence of a claw impression in tracks of snow leopard, the relative size difference between the front and rear pug marks, the walk pattern, and general shape and size of the pug marks. To estimate density from the average number of signs of presence encountered per $\mathrm{km}$ of transect, I used the criteria of Jackson \& Hunter (1996).

I interviewed local herdsmen using an open-ended questionnaire, and I talked with trekkers, hunters, and staff of Non-Governmental Organizations and the
Skardu Forest Department. Herdsmen were randomly selected for interview, whereas other groups were contacted based on information provided by various sources about their encounters with snow leopard signs (Table 1). In Area D information was gathered using questionnaires and interviews, but no biological surveys were conducted.

I considered evidence of snow leopard presence obtained from interviews to be confirmed or unconfirmed based on the quality and accuracy of the response. For example, some respondents who claimed to have made sightings gave accurate and vivid descriptions of the snow leopard's physical features and movement patterns, and in such cases the evidence was considered as confirmed. When the descriptions were less accurate the evidence was considered unconfirmed. With regard to reports of leopard signs, most of the confirmed signs were where herders had seen pug marks and gave accurate descriptions of these. I tested their identification capabilities by showing them unlabelled pug prints of the snow leopard together with bear, wolf and fox, and asked them to indicate which one they had seen. Most unconfirmed presence signs were where herders had seen other signs such as scat and spoor, or had been unable to provide sufficiently precise information to distinguish snow leopard signs from those of wolf. All hunters, trekkers and NGO and Forest Department staff provided accurate descriptions of leopard signs.

Density estimates for Areas A-C are based on the average number of signs of presence encountered per $\mathrm{km}$ of transect, whereas that for Area D is based on the information provided by villagers and staff of the Forest Department.

\section{Results}

The results of the transect surveys and interviews are given in Tables 2 and 3 respectively. Out of a total of 73 randomly selected herders from 24 villages in the four

Table 1 The four areas of Baltistan surveyed for snow leopard (Fig. 1), with survey dates, number of days spent surveying, and details of the number of herdsmen, hunters, trekkers and Forest Department and NGO staff interviewed in each area.

\begin{tabular}{|c|c|c|c|c|}
\hline & $\begin{array}{l}\text { Area A } \\
\text { (Hushey \& Saltoro) }\end{array}$ & $\begin{array}{l}\text { Area B } \\
\text { (Rondu Valley) }\end{array}$ & $\begin{array}{l}\text { Area C } \\
\text { (Skardu Valley) }\end{array}$ & $\begin{array}{l}\text { Area D } \\
\text { (Askoli, Biafo \& Baltoro) }\end{array}$ \\
\hline Total area $\left(\mathrm{km}^{2}\right)$ & 1,500 & 500 & 450 & 700 \\
\hline Survey dates (month/year) & $11 / 1998,9 / 2000$ & $7 / 1998,4 / 1999,9 / 2000$ & 8/1998, 4/1999, 9/2000 & $8 / 2000$ \\
\hline Number of days surveying & 26 & 19 & 14 & 4 \\
\hline Number of villages surveyed & 5 & 6 & 9 & 4 \\
\hline Number of herdsmen interviewed & 17 & 22 & 19 & 15 \\
\hline $\begin{array}{l}\text { Numbers of hunters/trekkers } \\
\text { interviewed }\end{array}$ & 4 & 6 & 2 & 2 \\
\hline $\begin{array}{l}\text { Number of Forest Department } \\
\text { \& NGO staff interviewed }\end{array}$ & 1 & 3 & - & - \\
\hline
\end{tabular}


Table 2 The number and total length of transects surveyed in the four areas, with the number and type of snow leopard signs found or heard, the mean number of signs, and the estimated number and densities of snow leopard (see text for details). The estimate of number and density of snow leopards for Area D was based on interview results only (see text for details).

\begin{tabular}{|c|c|c|c|c|}
\hline & $\begin{array}{l}\text { Area A } \\
\text { (Hushey and Saltoro) }\end{array}$ & $\begin{array}{l}\text { Area B } \\
\text { (Rondu valley) }\end{array}$ & $\begin{array}{l}\text { Area C } \\
\text { (Skardu valley) }\end{array}$ & $\begin{array}{l}\text { Area D } \\
\text { (Askoli, Biafo \& Baltoro) }\end{array}$ \\
\hline Number of transects & 190 & 90 & 75 & - \\
\hline Total length of transects (km) & 80 & 32 & 18 & - \\
\hline Number of signs found & 142 & 77 & 9 & - \\
\hline *Type of sign found & PM, ST, SP & PM, ST, SP & PM, GR & - \\
\hline Mean number of signs per $\mathrm{km}$ of transect & 1.77 & 2.4 & 0.5 & - \\
\hline Estimated number of snow leopards & $20-25$ & $6-10$ & $2-5$ & $8-10$ \\
\hline Estimated density per $100 \mathrm{~km}^{2}$ & $1.3-1.6$ & $1.2-2.0$ & $0.4-1.4$ & $1-1.5$ \\
\hline
\end{tabular}

*PM Pugmark, ST Scat, SP Scrape, GR Growl

survey areas (Table 1), 59 claimed to provide evidence of snow leopards' presence. Of these the authenticity of 21 claims could not be confirmed. 15 herdsmen reported sightings ( 9 confirmed) and 44 reported signs ( 29 confirmed). Out of 14 hunters and trekkers contacted, 12 provided evidence of snow leopard presence, of which the authenticity of only one could not be confirmed. Four hunters/trekkers reported sightings (3 confirmed) and eight reported signs (all confirmed). Four NGO and Forestry Department staff provided confirmed evidence of snow leopard presence in the survey areas. These included two cases of snow leopards caught in a corral, one case of seeing a carcass and one sighting. Based on the transect surveys and reports from herders, hunters, trekkers, government and NGO staff I estimate that 36-50 snow leopards are present in the surveyed area of $3,150 \mathrm{~km}^{2}$, giving a density of $1.1-1.6$ animals per $100 \mathrm{~km}^{2}$

Of the three areas where biological surveys were conducted, Area A, the Hushey and Saltoro range, had the highest numbers of reports of confirmed sightings (6). Snow leopard sightings and signs were common in this area, which had the highest estimated density of leopard of the four areas surveyed (Table 2). Of the three areas where biological surveys were conducted, Area B, the Rondu Valley, had the highest average number of signs encountered per $\mathrm{km}$ of transect (2.4). This is an area with a relatively high density of the snow leopard's ungulate prey species (IUCN, 1997a).

The snow leopard occurs in Area B in the central Rondu valley on both sides of the river Indus. Probably the populations on either side of the river are geographically isolated because the river serves as a major natural barrier. No presence signs of the snow leopard were observed in the Sari and Bagicha areas during the autumn 2000 surveys. This might be because of the timing of the survey, as snow leopards tend to remain at higher elevations until early to mid winter.
The three main areas where snow leopards occur in Area $C$ are Chunsa valley, Soq valley and Khepchun La. No reports of sighting or observation of presence were made outside these areas of good snow leopard habitat. From the high frequency of wolf signs in this region it is likely that the two species are competing for prey, especially as one of the snow leopard's prey species, wild goats, are uncommon in this area. Another prey species, long-tailed marmot Marmota caudata, occurs commonly throughout the area, but it is available only during summer months. In addition to wolf, fox Vulpes vulpes is common, and Lynx Lynx lynx is also found in the area.

The snow leopard is found on both sides of Askoli village in Area D, and herders reported that a healthy population of ibex Capra ibex siberica, a prey species, is found in the areas of the Biafo and Braldo glacier. The area stretching east of Askoli up to Payu on the Baltoro glacier is heavily used for trekking during the summer months, and reports by herders suggest that the snow leopard is consequently rare, or at least rarely seen, in this area. In addition to heavy human disturbance, the area is also characterized by a low density of snow leopard prey. Illegal hunting of ibex, blue sheep Pseudois nayaur and Ladakh urial Ovis orientalis vignei is frequently reported from this part of Baltistan.

\section{Discussion}

The total area of Baltistan is c. $25,000 \mathrm{~km}^{2}$, of which about one third can be considered to be good snow leopard habitat (i.e. with slopes $>40^{\circ}$ and presence of prey species). Based on the total available habitat and the density ranges estimated in this paper, I estimate that there are 90-120 snow leopards in Baltistan. The total potential snow leopard habitat in Pakistan is c. $80,000 \mathrm{~km}^{2}$ of which about half is considered suitable based solely on physical conditions (Fox, 1989). Using 
Table 3 Sightings and signs of snow leopards from personal observations, other than the surveys of Areas A-C (see text for details), and gathered from interviews with herdsmen, hunters, trekkers, Forest Department and NGO staff during 1998-2001, in the four areas surveyed in Baltistan (Fig. 1). See text for criteria used for confirmation.

\begin{tabular}{|c|c|c|c|c|}
\hline Date & Location & Evidence & Source & $\begin{array}{l}\text { Notes (including confirmed or } \\
\text { unconfirmed status of report) }\end{array}$ \\
\hline \multicolumn{5}{|c|}{ Area A (Hushey \& Saltoro) } \\
\hline 1994 & Kondus village & Caught in corral & $\begin{array}{l}\text { M. Hussain (Forest Dept staff), } \\
\text { pers. comm. }\end{array}$ & $\begin{array}{l}\text { Confirmed. One individual, later killed by } \\
\text { excessive tranquilisation. }\end{array}$ \\
\hline Nov 1998 & $\begin{array}{l}\text { Ailing, Chogolisa, } \\
\text { Ghondoghoro glaciers }\end{array}$ & $\begin{array}{l}\text { Signs (tracks } \\
\text { and scat) }\end{array}$ & Shafqat Hussain & Confirmed. Three individuals. \\
\hline Aug 1999 & Near Ghondoghoro & Sighting & $\begin{array}{l}\text { G. Mortenson (trekker), see } \\
\text { http://classic.mountainzone.com/ } \\
\text { climbing/99/karakoram/ } \\
\text { update-8-11bgreg.html } \\
\text { [accessed 23 October 2002] }\end{array}$ & Confirmed. One individual. \\
\hline Aug 1999 & Whole area & Sightings & Herdsmen interviews ${ }^{1}$ & $\begin{array}{l}\text { Of five herdsmen who reported sightings, } \\
\text { three were confirmed and two unconfirmed. } \\
\text { Number of animals could not be determined. } \\
\text { A common response was that snow leopards } \\
\text { are common all year round, and venture as } \\
\text { low as } 3,500 \text { m during summer. }\end{array}$ \\
\hline Aug 1999 & Whole area & Signs (tracks) & Herdsmen interviews ${ }^{1}$ & $\begin{array}{l}\text { Of } 11 \text { herdsmen who reported signs, eight } \\
\text { were confirmed and three unconfirmed. } \\
\text { Number of animals could not be determined. }\end{array}$ \\
\hline Sep 2000 & Whole area & Signs (old scats) & Shafqat Hussain & Confirmed. Number of individuals not known. \\
\hline Sep 2000 & Near Dumsum village & Signs (tracks) & Shafqat Hussain & Confirmed. Two individuals. \\
\hline Sep 2000 & Hushey village & Sighting & Hunter, pers. comm. ${ }^{1}$ & Confirmed. Reported sighting one animal. \\
\hline Sep 2000 & Near Ghondoghoro & Signs (tracks) & Two hunters, pers. comm. ${ }^{1}$ & Confirmed. Number of individuals not known. \\
\hline \multicolumn{5}{|c|}{ Area B (Rondu Valley) } \\
\hline Nov 1997 & Sari village & Caught in Corral & $\begin{array}{l}\text { Jawad Ali (NGO staff), } \\
\text { pers. comm. }\end{array}$ & $\begin{array}{l}\text { Confirmed. One individual later released } \\
\text { unharmed. }\end{array}$ \\
\hline Mar 1998 & Baghicha village & Sighting & M. Sikander (trekker), pers. comm. & Confirmed. One individual chasing a markhor. \\
\hline Apr 1998 & Basho village & Carcass & $\begin{array}{l}\text { Dr. M. Abbas (NGO staff), } \\
\text { pers. comm. }\end{array}$ & $\begin{array}{l}\text { Confirmed. One carcass seen buried in snow, } \\
\text { probably killed in avalanche. }\end{array}$ \\
\hline Apr 1999 & Skoyo village & Sighting & $\begin{array}{l}\text { M. Yaqub (Forest Dept staff), } \\
\text { pers. comm. }\end{array}$ & $\begin{array}{l}\text { Confirmed. A family of five, two adults and } \\
\text { three cubs. }\end{array}$ \\
\hline Apr 1999 & $\begin{array}{l}\text { Skoyo and Basho } \\
\text { villages }\end{array}$ & $\begin{array}{l}\text { Signs (scats, } \\
\text { spoor and tracks) }\end{array}$ & Shafqat Hussain & Confirmed. Number of individuals not known. \\
\hline Sep 1999 & Skoyo & Signs & $\begin{array}{l}\text { Mareile Oberstiener and Mathieu } \\
\text { Palay (trekkers), pers. comm. }\end{array}$ & Confirmed. Number of individuals not known. \\
\hline Sep 2000 & Whole area & $\begin{array}{l}\text { Signs (scat and } \\
\text { tracks) }\end{array}$ & Herdsmen interviews ${ }^{1}$ & $\begin{array}{l}\text { Of } 13 \text { herders who reported signs, } 11 \text { were } \\
\text { confirmed and two unconfirmed. Number of } \\
\text { individuals not known. }\end{array}$ \\
\hline Sep 2000 & Whole area & Sighting & Herdsmen interview ${ }^{1}$ & $\begin{array}{l}\text { Of four herdsmen who reported sightings, } \\
\text { two were confirmed and two unconfirmed. } \\
\text { Number of animals could not be determined. }\end{array}$ \\
\hline Sep 2000 & Sari & Sighting & Hunter, pers. comm. ${ }^{1}$ & Unconfirmed. \\
\hline Sep 2000 & Whole area & $\begin{array}{l}\text { Signs (tracks, } \\
\text { scat) }\end{array}$ & Two hunters, pers. comm. ${ }^{1}$ & Confirmed. Number of individuals not known. \\
\hline \multicolumn{5}{|c|}{ Area C (Skardu Valley) } \\
\hline Jan 1996 & Sadpara & Sighting & Herdsman interview ${ }^{1}$ & $\begin{array}{l}\text { Confirmed. Reported two individuals fleeing } \\
\text { to Chunsa valley after killing his } 31 \text { goats. }\end{array}$ \\
\hline Apr 1999 & Chunsa & Signs (growling) & Shafqat Hussain & Confirmed. Animal not sighted. \\
\hline Sep 2000 & $\begin{array}{l}\text { Chunsa, Soq and } \\
\text { Khepchun La }\end{array}$ & $\begin{array}{l}\text { Signs (tracks, } \\
\text { scat) }\end{array}$ & Shafqat Hussain & Confirmed. Two individuals. \\
\hline Sep 2000 & Khepchun La & Sighting & Herdsmen interviews $^{1}$ & $\begin{array}{l}\text { Two reports of sightings, one confirmed, one } \\
\text { unconfirmed. Number of individuals could } \\
\text { not be determined. }\end{array}$ \\
\hline Sep 2000 & Whole area & Signs & Herdsmen interviews ${ }^{1}$ & $\begin{array}{l}\text { Of } 10 \text { herdsmen who reported signs, four } \\
\text { were confirmed and six unconfirmed. } \\
\text { Number of individuals not known. }\end{array}$ \\
\hline
\end{tabular}


Table 3 (Continued)

\begin{tabular}{|c|c|c|c|c|}
\hline Date & Location & Evidence & Source & $\begin{array}{l}\text { Notes (including confirmed or } \\
\text { unconfirmed status of report) }\end{array}$ \\
\hline \multicolumn{5}{|c|}{ Area D (Askoli, Biafo \& Baltoro) } \\
\hline Aug 2000 & Whole area & $\begin{array}{l}\text { Signs (tracks, } \\
\text { scat, pelts) }\end{array}$ & Herdsmen interviews ${ }^{1}$ & $\begin{array}{l}\text { Of } 10 \text { herdsmen who reported signs, six were } \\
\text { confirmed and four unconfirmed. Number of } \\
\text { individuals not known. }\end{array}$ \\
\hline Aug 2000 & Whole area & Sighting & Herdsmen interviews ${ }^{1}$ & $\begin{array}{l}\text { Of three herdsmen who reported sightings, } \\
\text { two were confirmed and one unconfirmed. }\end{array}$ \\
\hline Aug 2000 & Whole area & Signs (tracks) & Hunters, pers. comm. ${ }^{1}$ & Number of individuals unknown. \\
\hline
\end{tabular}

${ }^{1}$ It was not possible to obtain precise dates for reports of sightings or signs from herdsmen and hunters, as they do not tend to organise their recollections according to the calendar year. The dates therefore represent the time of interview rather than the time of sighting, but all events recorded appeared to have occurred within the last 5 years.

data from IUCN surveys (1997a, b) I estimated that the density of the snow leopard's main prey species, ibex and markhor in the survey areas in Baltistan is c. 0.5 animals per $\mathrm{km}^{2}$, and that about one third of the total potential snow leopard habitat in Pakistan, c. $27,000 \mathrm{~km}^{2}$, supports this density of prey. Based on this area of habitat and using the population density range for snow leopard from my surveys, I estimate that 300-420 snow leopards are potentially present in Pakistan.

Throughout its range the snow leopard is persecuted by local farmers because of its predation of domestic livestock. Numerous studies have described retaliatory killing of the snow leopard by farmers as the biggest threat to the survival of the species in the wild (Jackson, 1979, 1988; Schaller et al., 1987, 1988; Fox, 1989; Fox et al., 1991; Nowell \& Jackson, 1996; Jan, 1997; Malik, 1997). In a study in the Indian Himalayas, Mishra (1997) found that local people had an extremely negative attitude towards the snow leopard because of the hardship that it caused them. A similar attitude has been recorded by Schaller et al. (1988) in Xinjiang province in China, and by Mallon (1984) in central Ladakh. On average, it has been estimated that in some areas the annual rate of loss of domestic livestock amounts to $2-5 \%$ of the total herd size (Mallon, 1984; Fox et al., 1991; Oli et al., 1994; Mishra, 1997; P. Jackson \& J. Mock, pers. comm.).

Data on the number of snow leopards killed by farmers each year is scant. Schaller et al. (1988) reported that 12 snow leopards were killed by local people in the Xinjiang Province of western China in 1985-86. Fox et al. (1991a) believed that 5-10 snow leopards were killed in central Ladakh between 1983 and 1988. Osborne et al. (1983) give a figure of five snow leopards killed in southern Ladakh between 1978 and 1982. The main methods described for killing were shooting, poisoning the carcasses of prey species, and trapping using leg snares.
Laws that sanction the killing of problem animals that threaten the life or property of humans are widely used in some countries (Nowell \& Jackson, 1996), and some farmers abuse such law to justify the random killing of wild predators (Swank \& Teer, 1989; Nowell \& Jackson, 1996; Coniff, 1999). There is a provision under section 22 of the Northern Areas Wildlife Preservation Act 1975 that sanctions the eradication of problem animals. Under this provision a designated official of the wildlife department or a private individual can eradicate an animal that threatens private property or human life. In cases where an animal inflicts damage to property, such as by killing livestock, there is, however, no mechanism for compensation to the affected individual. I noticed during the surveys that few farmers knew about the law sanctioning the killing of problem animals, and that even where farmers were aware of the law they stated that they were unlikely to make use of it because of fear of becoming entangled with the state over any legal issue. They felt that the state would be unlikely to believe them, and would punish them for illegal acts. In addition, there have been at least five incidents in the Northern Areas in the last 5 years, two of which were in Baltistan, when a snow leopard, after been caught in a corral, and inflicting heavy livestock loss, was released unhurt by the villagers on the orders of the government. In no case did the government pay compensation to the affected farmers despite repeated promises (Jawad Ali, pers. comm.).

However, while this state of affairs may stop farmers from openly persecuting the snow leopard, it does not stop them from killing the snow leopard secretively. Hussain (2000) estimated that during 1997-1999 at least four snow leopards were killed in the Northern Areas of Pakistan, and Schaller (1976) estimated that during 1971-1973 at least seven snow leopards were shot in the vicinity of Chitral Gol National Park in north-western Pakistan. While the local farmers in Baltistan may not 
be aware of the relevant law, or may not have the confidence to use it, government staff and conservation NGOs are aware of these laws. Local farmers complain of snow leopard predation of domestic livestock throughout the snow leopard's range in Pakistan. In this situation government staff, and particularly conservation NGOs who now increasingly claim to represent the interests of both the snow leopard and local people, need to balance the rights of the farmers with a justified fear that should the law sanctioning the killing of problem animals become widely known it may be abused.

Poaching for body parts and pelts is another threat to the snow leopard in Baltistan. Poaching occurs mainly in the winter when the snow leopard comes down to the valleys, close to villages. During my visit in winter 2001 I was told that in Shigar valley snow leopards are trapped using leg snares and then either killed immediately using clubs, or starved to death (I was not able to obtain details such as numbers of animals killed per year, as the subject is sensitive). The snow leopards are not shot, as this destroys the pelt, which is sold to merchants in Skardu market. These pelts are of good quality: the animal is intact, and is stuffed with hay. From Skardu the pelts are taken to Peshawar for domestic buyers around the country and for foreign buyers in the Arab Gulf States and Europe. Although information is hard to obtain, I was told that a well cured pelt can fetch as much as US \$400 in Skardu. In addition to supplying pelts to Skardu, the trappers also supply pelts to buyers in Shigar valley, where there is a heavy traffic of local and foreign trekkers in summer.

I believe that the trapping of a snow leopard takes place with the consent of the whole village, which means it will be difficult to stop. The individual trapper risks engaging in an illegal trade because of the potential high return. A successful sale is equivalent to 1 years' cash income for an average family in Baltistan. The community gains because the death of the snow leopard means a reduced threat to their livestock. Therefore, unless there are strong incentives to conserve the snow leopard for the whole community, it is unlikely that trapping will cease. Currently there are strong collective and individual incentives to eradicate the snow leopard, and no collective incentives to conserve it.

Recent conservation efforts in Northern Pakistan have resulted in the organization of trophy hunting of mountain ungulates, such as ibex, by foreign sportsmen. The hunts are arranged as part of a Government of Pakistan and UNDP funded, and IUCN implemented, Mountain Areas Conservancy Project. Since 1997 approximately eight hunts have taken place in six villages in Baltistan, and there is a demand for more hunts, particularly from North American hunters. A major part of the hunting fee goes to the participating communities as an incentive for ongoing conservation of these ungulates.

However, for the snow leopard (and other predators of wild ungulates) this programme may have a negative impact. In the six villages in Baltistan where the trophy hunting programme has been introduced, community members mentioned to me that they now have two motives to kill the snow leopard: protection of livestock and protection of wild ungulates. This concern for wild ungulate conservation is certainly new amongst these villagers and can be mainly attributed to the introduction of the trophy hunting programme. Each hunt brings $c$. US $\$ 4,000$ to a village, a substantial sum for these subsistence farmers, providing them with a strong motivation to maximize the number of ungulates in the vicinity of their village. A solution to the potential conflict between leopard and ungulate conservation would be to develop a more holistic approach to conservation in the region. If an economic incentive approach to biodiversity conservation is to be promoted then incentives should be built around the whole ecosystem and not just around one species.

The snow leopard in Baltistan seems to be widely but thinly distributed. Its status, although precarious, may be better than suggested by Schaller's earlier survey (1976). The main threat to the snow leopard in this region is retaliatory killing of leopards that threaten the economic livelihoods of the local people by preying on domestic livestock. It is therefore necessary that snow leopard conservation should be addressed within the context of local livelihoods, creating effective economic and other incentives, and appropriate social institutions, to ensure collective and not just individual interest in snow leopard conservation. It is also imperative that conservation initiatives in this region that focus on single species should take into account adverse effects on other species in the ecosystem. For example, any ungulate management programme that involves trophy hunting must consider its impacts on large predators such as snow leopards and wolves.

Although some retaliatory killings of snow leopard appear to be occurring in Baltistan, at the moment the effect of the relatively poor subsistence farmers of the district on the snow leopard, because of the lack of information and power available to them, is relatively benign. While this may be positive in terms of conservation outcome, it cannot be viable or equitable in the long term to expect poor farmers to 'subsidise' the snow leopard's existence. Conservationists must pay attention to the demands of the local communities and develop conservation initiatives with them. It is equally important to ensure that there is genuine cooperation with the local government. Successful conservation will only come about through innovative and dynamic interventions 
that develop genuine and sustainable local commitment. This will entail a long-term process that must, at least initially, focus on improving and protecting local people's livelihoods, rather than subordinating these to short-term conservation goals.

\section{Acknowledgements}

I would like to thank Mr. Jawad Ali, Manager Forestry section, Aga Khan Rural Support Programme (AKRSP), Skardu, for providing guidance and logistical support throughout the research period. I am particularly indebted to Ali Mohammad and Ghulam Mehdi who accompanied me on all field surveys and acted as guides, cooks and porters. My special thanks to all the villagers who participated in this research. I am also grateful to two reviewers who provided constructive criticism of the paper. A special thanks to Annie Harper, who read the manuscript many times and suggested many constructive changes.

\section{References}

Coniff, R. (1999) Cheetah: Ghosts of the Grasslands. National Geographic, 22, 2-31.

Fox, J. (1989) A Review of the Status and Ecology of the Snow Leopard. International Snow Leopard Trust, Seattle, USA.

Fox, J., Sinha, S., Chundawat, R. \& Das, P. (1991) Status of the Snow Leopard Panthera uncia in Northwest India. Biological Conservation, 55, 283-298.

Hussain, S. (2000) Protecting the snow leopard and enhancing the farmers' livelihoods: a pilot insurance scheme in Baltistan. Mountain Research and Development, 20, 224-229.

IUCN (2002) 2002 IUCN Red List of Threatened Species. http:/ / www.redlist.org [accessed 21 September 2002].

IUCN, Pakistan. (1997a) Ibex Conservation Plan - Hushey. Unpublished Report, IUCN, Gilgit, Pakistan.

IUCN, Pakistan. (1997b) Wildlife Conservation Plan - SkoyoKarbathang-Basingo (Skardu District). Unpublished Report, IUCN, Gilgit, Pakistan.

Jackson, R. (1979) Snow Leopard in Nepal. Oryx, 15, 191-195.

Jackson, R. (1988) Threatened Wildlife, Crop and Livestock Depredation and Grazing in the Makalu-Baran Conservation Area. Woodland Mountain Institute, WV, USA.

Jackson, R. \& Hunter, O.D. (1996) Snow Leopard Survey and Conservation Handbook. International Snow Leopard Trust and US Geological Survey, Seattle, USA.

Jan, A. (1997) Opening Remarks. In Proceedings of the Eighth International Snow Leopard Symposium (eds R. Jackson \& A. Ahmed), pp. xii-xiv. International Snow Leopard Trust, Seattle, USA.
Malik, M. (1997) Status and Conservation of Snow Leopard in Pakistan. In Proceedings of the Eighth International Snow Leopard Symposium. (eds R. Jackson \& A. Ahmed), pp. 11-20. International Snow Leopard Trust, Seattle, USA.

Mallon, D. (1984) The Snow Leopard in Ladakh. In International Pedigree Book of Snow Leopards. 4, 23-37. Leif Blomqvist, Helsinki Zoo, Helsinki, Finland.

Mishra, C. (1997) Livestock depredation by large carnivores in the Indian trans-Himalaya: conflict perceptions and conservation prospects. Environmental Conservation, 24, 338-343.

Nowell, K. \& Jackson, P. (1996) Wild Cats: Status Survey and Conservation Action Plan. IUCN/SSC Cat Specialist Group, Gland, Switzerland.

Oli, K.M., Taylor, R.I. \& Rogers, E.M. (1994) Snow leopard predation of livestock: An assessment of local perceptions in the Annapurna Conservation Area, Nepal. Biological Conservation, 68, 63-68.

Osborne, B., Mallon, D. \& Fraser, S. (1983) Ladakh, threatened stronghold of rare Himalayan mammals. Oryx, 17, 182-189.

Schaller, G. (1976) Mountain Mammals in Pakistan. Oryx, 13, 351-356.

Schaller, G., Hong, L., Talipu, LuHua, Junrang, R., Mingjian, Q. \& Habin, W. (1987) Status of large mammals in Taxkorgan Reserve, Xinjiang, China. Biological Conservation, 42, 53-72.

Schaller, G., Hong, L., Talipu, Junrang, R. \& Mingjian, Q. (1988) The snow leopard in Xinjiang, China. Oryx, 22, 197-204.

Schaller, G. (1988) Stones of Silence: Journeys in the Himalayas. The University of Chicago Press, Chicago, USA.

Swank, W. \& Teer, J. (1989) Status of the Jaguar - 1987. Oryx, 23, 16-23.

Wegge, P. (1989) Khunjerab National Park: ecological status and management recommendations. International Workshop on the Management of Planning of Khunjerab National Park: Proceedings (ed. B.G. Bell), pp. 95-114. Government of Pakistan, National Council for Conservation of Wildlife and IUCN, Islamabad, Pakistan.

\section{Biographical sketch}

Shafqat Hussain's main research interest is in examining the interaction of local communities and wildlife to facilitate the implementation of solutions to conservation problems. He is particularly interested in understanding how models for collective cooperation may be developed between local communities and implementing agencies. He has developed a livestock insurance scheme against snow leopard predation in Baltistan, Northern Pakistan, implemented by the local community in collaboration with a commercial trekking company. 